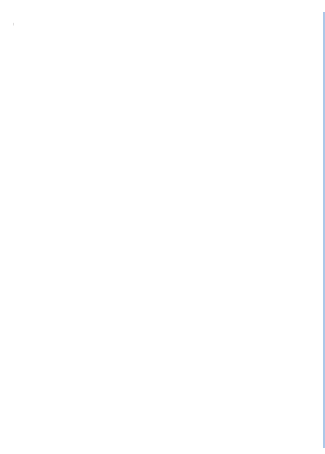

\section{Journal of Geology. Geography and Geoecology}

ISSN 2617-2909 (print)

ISSN 2617-2119 (online)

Journ. Geol. Geograph. Geology, 30(4), 781-793. doi: $10.15421 / 112172$

Tuzyak Ya. M., Ivanina A. V., Hotsanyuk H. I., Shaynoha I. V., Cherniak A. Ya. Journ. Geol. Geograph. Geoecology, 30(4), 781-793

\title{
From paleontological collections to the Paleontological Museum of Lviv University as an object of historical, cultural and natural values
}

\author{
Yaryna M. Tuzyak, Antonina V. Ivanina, Halina I. Hotsanyuk, Ihor V. Shaynoha, Andrii Ya. Cherniak \\ Ivan Franko National University of Lviv, Lviv, Ukraine, yarynatuzyak@gmail.com
}

Received: 02.10 .2021

Received in revised form: 26.10 .2021

Accepted: 09.11.2021

\begin{abstract}
The creation of the Paleontological Museum of Lviv University is the implementation of one of many projects of scientists of geologists and paleontologists in the territory of first Eastern Europe, and later modern Western Ukraine. The foundation of the «temple of muses» of geological sciences (natural sciences, Earth sciences) and their
\end{abstract} component of paleontology in the West of Ukraine is the stage of formation of geological (paleontological) research and the Lviv geological (paleontological-stratigraphic) school at the Lviv University. The beginning and development of natural sciences - geology and paleontology on a global scale became the basis for the creation of the Geological Faculty and the Department of Historical Geology and Paleontology (1945) at the Lviv University, and the Geological/Paleontological Museum acquired importance in the study, collection, conservation, protection, and popularization of Earth Sciences among various segments of the population. The history of the foundation and the development of the Geological/Paleontological Museum of Ivan Franko National University of Lviv is covered. Prerequisites that contributed to the foundation of the Paleontological Museum are given, the scientific and theoretical concept based on it, the directions of research and the results of achievements of each stage are substantiated. The museum place in the «spectrum» of historical, cultural and natural values has been clarified. The scientific research works of different generations of geologists and paleontologists over the 200-year history and their contribution to the development of Earth Sciences were analyzed. Its significance as a cultural and spiritual center for the development of society is highlighted. The description of the activity of the scientific goals of various political systems in which the territories of the West of Ukraine were located and their contribution to the development of the Paleontological Museum is given. The structure and classification of natural objects (fossils, naturals) of museum collections and foundations by purpose and significance have been determined. Modern and further trends in the development of the Paleontological Museum have been clarified. Fundamental, research, educational and informative, cultural, propaganda aspects of the Paleontologic Museum are shown.

Keywords: Paleontological Museum of Lviv University, fossils, naturalia, museum collections, expositions, foundations.

\section{Від палеонтологічних колекцій до Палеонтологічного музею Львівського Університету як об'скта історичних, культурних і природних цінностей}

\author{
Я. М. Тузяк, А. В. Іваніна, Г. І. Гоцанюк, І. В. Шайнога, А. Черняк \\ Львівський національний університет імені Івана Франка, Львів, Украӥна, yarynatuzyak@gmail.com
}

\begin{abstract}
Анотація. Створення Палеонтологічного музею Львівського Університету - це втілення в життя одного із багатьох проектів науковців геологів й палеонтологів на теренах спочатку Східної Європи, а згодом сучасної Західної України. Заснування «храму муз» геологічних наук (природничих наук, Наук про Землю) і їх складової палеонтології на Заході України - це етап становлення геологічних (палеонтологічних) досліджень та Львівської геологічної (палеонтолого-стратиграфічної) школи у Львівському Університеті. Започаткування і розвиток природничих наук - геології й палеонтології у світовому масштабі стало підгрунтям для створення Геологічного факультету й Кафедри історичної геології та палеонтології (1945) у Львівському Університеті, а Геологічний/Палеонтологічний музей набув важливого значення з вивчення, колекціонування, збереження, охорони, і популяризації Наук про Землю серед різних верств населення. Висвітлено історію заснування і розвитку Геологічного/Палеонтологічного музею Львівського національного університету імені Івана Франка. Наведено передумови, які сприяли закладенню Палеонтологічного музею, обгрунтовано науково-теоретичну концепцію, покладену в його основу, напрями досліджень і результати досягнень кожного етапу. 3'ясовано місце музею у «спектрі» історико-культурних і природних цінностей. Проаналізовано науково-дослідний доробок різних поколінь геологів й палеонтологів за 200-річну історію та їхній внесок у розвиток Наук про Землю. Висвітлено його значення як культурного й духовного центру для розвитку суспільства. Схарактеризовано діяльність наукових осередків різних державних устроїв, в яких перебували терени Заходу України, та їхній внесок у розвиток Палеонтологічного музею. Визначено структуру й класифікацію природних об'єктів (фосилій, натуралій) музейних колекцій і фондів за призначенням та значимістю. З’ясовано сучасні й подальші тенденції розвитку Палеонтологічного музею. Показано фундаментальний, науково-дослідний, навчально-пізнавальний, культурно-освітній, просвітницький, пропагандистський аспекти Палеонтологічного музею.
\end{abstract}

Ключові слова: Палеонтологічний музей Львівського Університету, фосилії, натуралії, музейні колекиії, експозиції, фонди. 
The Nature has taken care of everything, that everywhere you find something to learn.

Leonardo da Vinci

We are becoming less university museums and more universities in museums.

M. King

The highest value of human knowledge is to understand the Creator's purpose.

Ya. Tuzyak

\section{Introduction}

Museums are a treasury of historical, natural and cultural heritage, and museum exhibits are carriers of invaluable information about the history, nature and culture of the region. The main task of museums of a new type or «third generation museums» is to fulfill not only the traditional function of being scientific and spiritual centers, but also museums that offer a new vision, a new understanding, new acknowledgement of a particular problem, museums that develop, produce and promote new ideas.

The Paleontological Museum of Lviv University is the «Temple of Muses» of the Earth Sciences, collecting, storing, exhibiting the remains of flora and fauna $(95 \%)$ - the creations of Nature, most of which are preserved in stone. They represent a value as an evidence of life existing on the planet Earth hundreds, millions and billions of years ago, are reliable indicators of habitats, tools for reconstructing paleoecosystems of past geological eras and their position in space and time, tools for determining the relative geological age of rocks. In addition, well-preserved fossils create an idea of the morphological features of organisms that lived in the distant past, their way of life. They also play a major role in elucidating the «biography» of the Earth - a sequence of events reproduced by scientists in the completeness of the geological and paleontological record. And at the present stage, biotic events occupy an important place (out of 100 stages of the International chronostratigraphic chart (ICC) in 77, the geological boundary is determined by biotic criteria, most of which are primary, and in other cases, when the primary marker is abiotic, paleoorganisms have the role of secondary markers). Sedimentary rocks of biogenic origin (organogenic limestones, marbles) are a unique natural decorative stone that has been widely used later in architecture and construction (lining, decoration, paving, construction, carving sculptures, interior objects, etc.). Historical and architectural monuments have been erected from this material that belong to the historical and cultural heritage of the national and world importance (UNESCO). In particular, the ensemble of the historical center of Lviv was included into the the UNESCO World Heritage Register in 1998. A significant part of the city's engineering structure has been erected or has a natural decorative stone in its interiors. Fragments (samples) of these stones form a separate exposition in the Paleontological Museum of the Lviv University.

Today, as a result of the temporarily occupied territories (in particular, the annexation of the Autonomous Republic of Crimea by the Russian Federation) and the introduction of quarantine restrictions due to the spreading of the COVID-19 pandemic, visiting and studying the natural eco-morphodynamic systems of certain regions of Ukraine during training practices (field stage) and research expeditions has become limited or impossible. Also, the territories of the Nature Reserve Fund of Ukraine become difficult to study and select individual paleontological objects. Active business development and excessive use of the Earth's subsoil in order to seize the natural resources of various origins for the growth and strengthening of the mineral resource base of Ukraine led to the destruction, and in some cases complete extinction, of unique and unrepeatable natural eco-morphodynamic systems that cannot be recreated. All this increases the importance of museum collections as the sources of information and natural monuments. In addition, Paleontological museums store unique and rare fossil forms that exist on planet Earth in a single copy, or are known only in a few places. And this, in turn, makes it possible to consider museum collections and museums in general, not only as a national scientific asset (historical, memorial), but also as a separate type of geological property objects - paleontological natural monuments.

In the process of analyzing published sources, it was found that the emergence of the Geological/ Paleontological Museum, first in Eastern Europe, and subsequently in the West of Ukraine at Lviv University, has a long history, is closely connected with the stage of formation of geology and its component of paleontology on a global scale (Bilonizhka, Matkovsky, Pavlun', Slyvko, 2010; Bilonizhka, Matkovsky, Pavlun', Slyvko, Ivanina, 2020; Vyalov, Venglinsky, Golev, Goretsky, Gorbach, Kudrin, 1956; Leschukh, Ivanina, Hotsanyuk, Shainoha, Tuzyak, 2006; Tuzyak, 2021; Tuzyak, 2021a; Tuzyak, 2021b, etc.). An outstanding role in the establishment of these studies belongs to the city of Lviv - the main cell where the institutions involved in the geological study of the territory of Eastern Europe, the creation of the Geological Atlas of Galicia ("Atlas geologiczny Galicyi". 1884-1911. Scale 1:75000), the first finds and collections of fossils are concentrated (19th century, 1825-1850).

\section{The aim of the study.}

The purpose of the article is to highlight the foundation first of the Geological and later the Paleontological Museum of Lviv University in Western 
Ukraine, the history of the formation and development of the «temple of muses» of geological/paleontological sciences, the contribution of researchers in geology and paleontology of different generations and periods in the development of Earth sciences, modern trends and the place of the Paleontological Museum in the system of historical, cultural and natural values.

\section{The article states:}

1. Prerequisites for the emergence of the Geological and later Paleontological Museum of Lviv University.

2. Stages of formation and development of the Geological/Paleontological Museum in the West of Ukraine.

3. Directions of development and activity of the Geological/Paleontological Museum of Lviv University for 200-year period.

4. Analysis of published works using museum funds (collections) as research objects.

5. The results of research on fossils in the West of Ukraine and beyond.

6. Contribution of researchers in geology and paleontology of different generations and periods in the process of formation and development of the Geological/Paleontological Museum.

7. Classification of museum collections and foundations by purpose and significance.

8. Substantiation of the uniqueness, rarity and value of museum exhibitions and collections.

9. Modern and further trends in the development of the Paleontological Museum.

10. The place of the Paleontological Museum of Lviv University in the system of historical, cultural and natural values.

\section{Materials and methods}

The material for writing the article was a review and analysis of the collections and funds of the Paleontological Museum of Lviv University, publications on these topics, regulatory acts, laws and regulations.

In the study of the history of systematization of fees and funds of the Paleontological Museum, classification of exhibition and exhibition collections, determination of their significance and justification as the objects of National and Natural (Geological) Heritage, the main methods were statistical, comparative-historical, regulatory, modern information technologies.

Over the almost 200-year history of the formation of the Geological/Paleontological Museum of Lviv University, information about it was published in the form of short messages - theses of conferences (Voloshynovska, Hotsanyuk, Ivanina, Leschukh, Maryash, 2015; Voloshynovska, Hotsanyuk, Leschukh, Ivanina, 2004; Tuzyak, 2021; Tuzyak, 2021a; Tuzyak,
$2021 \mathrm{~b}$, etc.), articles in periodicals and reference publications (Bilonizhka, Matkovsky, Pavlun', Slyvko, 2010; Bilonizhka, Matkovsky, Pavlun', Slyvko, Ivanina, 2020; Leschukh, Ivanina, Hotsanyuk, Shainoha, Tuzyak, 2006, etc.), guides (Vyalov, Venglinsky, Golev, Goretsky, Gorbach, Kudrin, 1956), popular scienticif publications. However, there is insufficient information about museum collections and funds among the published materials, which are replenished annually due to the field stages of training practices, research expeditions, geological excursions, gifts, etc., the issue of assessing their value is not adequately covered. At the present stage, the disclosure of various areas of activity of the Paleontological Museum is relevant in order to clarify its place in the system of historical, cultural and natural values to justify the granting of the status of the National Heritage. The priority in this direction is to highlight the importance of museum funds and collections at the national level, for universities and various segments of the population. At the national level, these are unique fees and territories, unique in their kind. Each individual Paleontological Museum (or paleontological department in the Natural Museum) has its own history of formation and development, the number and value of collections, consisting in their uniqueness, and its own research work with outstanding figures. For higher education institutions - this institution which should be stored and protected for the real and future generations for the purpose of carrying out research, educational and informative, educational and cultural, popularizing activity. Museums are one of the means of combating the deculturation of the population - an understanding of the culture of their people, natural wealth and historical values, outstanding figures of a particular field of sciences.

At the present stage, the cultural and creative function of higher education institutions (including museums as their components) is to combine three elements: technology (widespread introduction of innovative technologies), talent (attracting creative personalities who can produce new knowledge) and tolerance (perception of new ideas and concepts). It is gaining active development in those regions that are the cells of universities where the so-called concept of «Three T» by Richard Florida is present (Muravska, 2018). The creation of a creative personality is possible provided that the development of an innovative infrastructure is ensured as a means of transmitting research, ideas and approaches. Such centers are institutions of higher education (including museums), which accumulate monuments and treasures of nature, human culture, etc., promote knowledge not only for their community, but also for various segments of the population, innovative means. Such institutions support local communities with their experience and knowledge, promote scientific 
knowledge, contribute to the development of academic values, and revive urban life, in particular by organizing exhibitions and events. These projects, in turn, contribute to the development of cultural tourism. And the greater the share of university representatives in the demographic structure of the city, the greater the role the institution will play in outlining its cultural image. It should be added that the Paleontological Museum, on a limited area, presents such a variety of fossils «in space and time» that is impossible in a natural environment. This helps to attract museum collections to the educational process.

\section{Results}

Milestones of the history of formation and stages of development of the Paleontological Museum of Lviv University. The Paleontological Museum of Lviv University is one of the oldest museums in Eastern Europe, the foundations of which were laid in the first half of the $19^{\text {th }}$ century, and the only institution in Ukraine with the largest number of exhibits (in other Natural Museums of Ukraine, collections of fossils form separate departments or exhibitions). Museum funds and collections count more than 18 thousand units of rare, valuable and unique paleontological and geological samples found in different-age sediments of all continents. They reflect the research developments of more than one generation of geologists and paleontologists working at Lviv University from the time of its foundation until today and can be considered as the scientific, cultural and memorial Heritage of Ukraine.

Four prerequisites contributed to the emergence of the Paleontological Museum - as an independent structural unit of Lviv University: 1) the first paleontological collections begun in the first half of the $19^{\text {th }}$ century, related to the geological study of the territory of Eastern Europe and the creation in the second half of the $19^{\text {th }}$ century. Geological Atlas of Galicia, the accumulation of the first actual (geological and paleontological) material; 2) replenishment of museum funds with collections of famous geologists and paleontologists of various periods, creation of new expositions; 3 ) the formation of geology and its component of paleontology as a science at Lviv University; 4) the foundation of the Lviv Paleontological and Stratigraphic School, the Lviv branch of the Paleontological Society (1951), the beginning of the publishing house «Paleontological Collection» (1961) in the West of Ukraine.

The prerequisites for the development of Natural Museums in general and the Geological/Paleontological Museum in particular, in the world and domestic dimension, laid the foundation for the first educational centers with the awareness of the museum as an educational institution and the promotion of natural values and natural sciences. Today, the activities of the Paleontological Museum can be outlined by a model: science-education-popularization.

The formation of the Geological/Paleontological Museum covers a 200-year development period and has the following characteristics:

A long (almost 200 years) and complex history of formation and development. According to state devices political systems in the region (Austro-Hungarian 1772-1918, Polish - 1918-1939, Soviet-1939-1991, and modern, Ukrainian - since 1991 until now), the collection and study of fossils were carried out by researchers of different generations and nationalities Austro-Hungarians, Poles, Russians, Ukrainians, etc. Among them are Z. Pazdro, V. Zych, V. Rogala, R. Zuber, Ya. Charnotsky, B. Kokoshynska, L. Gorbach, V. Kudrin, V. Sheremeta, O. Vyalov, V. Goretsky, Ya. Kulchitsky, R. Leshchukh, A. Ivanina, V. Uziyuk, etc.

A significant stratigraphic range of deposits in which paleoorganisms (macro- and microfossls) are found. Museum collections and works published over 200 years contain information about fossils floras and faunas, the age-old interval of which covers almost the entire Phanerozoic part and the upper part of the Precambrian (Vendian/Ediacaran) and ranges from 670$540 \mathrm{Ma}$ ago to this day.

Research and identification of remains in various structural-tectonic elements of the sedimentary cover of Ukraine and the World (platform and complex areas).

Significant geography of paleontological remains come not only from the territory of Ukraine, but also from regions of other continents.

Use of museum exhibits for research, educational and popularization purposes.

Since foundation until present time, three stages in the history of the Geological/Paleontological Museum can be distinguished.

1. Austro-Hungarian-Polish (early $19^{\text {th }}$ centuries 1939). The basis of museum foundation at that time was the collection of remains of paleoorganisms, founded in the first half of the $19^{\text {th }}$ century (in 1825). The collections of the ancient fauna of the famous Austrian geologist Ludwig Zeischner were the first paleontological foundations, first (since 1852) exhibited in the Mineralogical Museum, and subsequently in the newly created Geological Museum. In 1905, on the basis of paleontological and geological collections, the foundation of the «temple of muses» of natural (geological) sciences was laid and an independent structural unit was created - the Geological Museum, initiated by Professor R. Zuber (the first head of the Department of Geology). During this period, museum collections were replenished with samples originating 
from the expanses of Western and Eastern Europe and other continents.

2. Soviet (1939-1991). Museum funds were replenished as a result of educational and production practices, conferences, symposia, colloquiums and monographic collections of research works. At the same time, the museum's collections and exhibitions are used for research, educational and popularization purposes. Thanks to the events of this period, museum funds were replenished with exhibits originating from the regions of the former USSR.

3. Modern, Ukrainian (since 1991 until now). In 2004, by decision of the Academic Council of the University, the Geological Museum was renamed to the Paleontological Museum, since $95 \%$ of its museum exhibits are diverse remains of micro- and macrofossils of different age ranges. Collections of paleontological

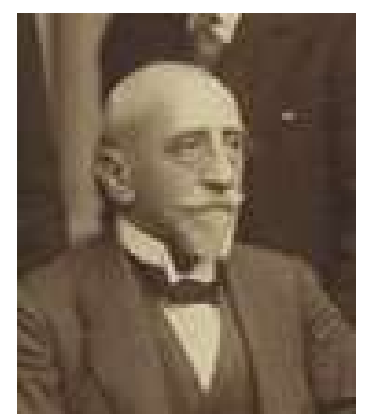

Rudolf ZUBER (1905-1924)

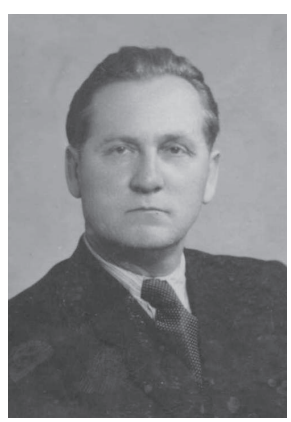

Vasil GORETSKY (1946-1949)

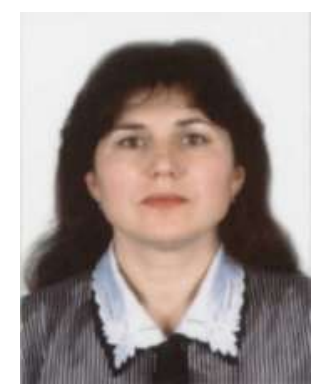

Olga VOLOSHYNOVSKA (1986-2016)

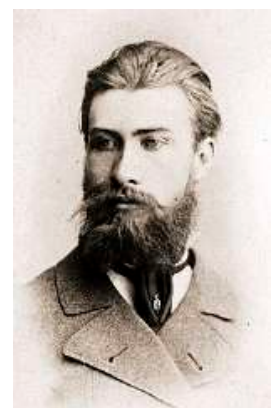

Józef SIEMIRADZKI (1924-1933)

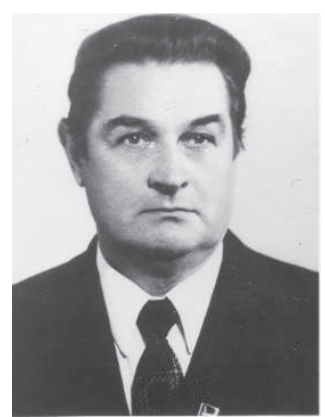

Ivan VENGLINSKY (1947-1953)

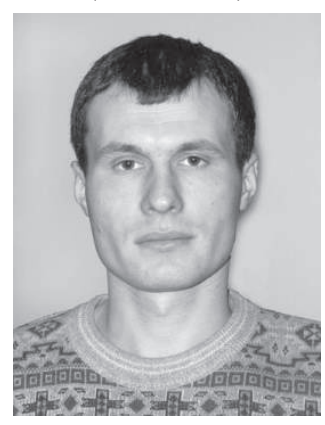

Andriy DANYLIV (2016-2021)

objects collected in the territory of Ukraine in the process of research, field stages of educational practices, conferences and gifts continue to be replenished. New expositions are decorated - «Routes of educational practices», «Fossils of the Neogene of Lviv and its environs». Every year, the museum is visited by more than 4000 visitors - students of various educational institutions, students of schools, lyceums, colleges, tourists and guests of the city, Lviv residents.

Geological, and subsequently Paleontological Museum in different years was headed by (Fig. 1): R. Zuber (1905-1924), J. Siemiradzki (1924-1933), J. Samsonowicz (1935-1939), B. Kokoshynska (19391946), V. Goretsky (1946-1949), I. Venglinsky (19491953), Z. Khmilevsky (1953-1977), L. Kosarchyn (1979-1986), O. Voloshynovska (1986-2015), A. Danyliv (2015-2021).

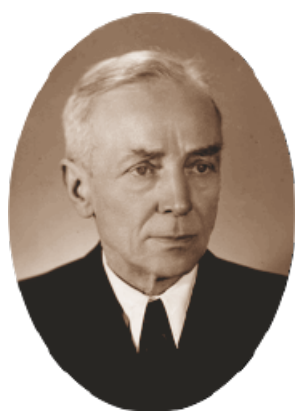

Jan SAMSONOWICZ (1935-1939)

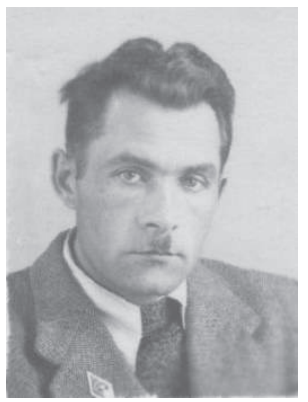

Zinovy HMILEVSKY (1958-1978)

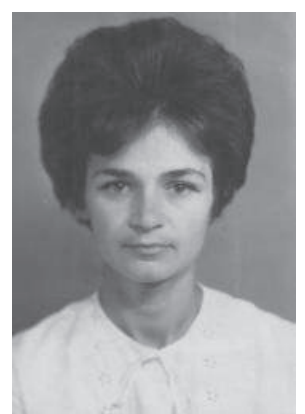

Hrystyna MEDVEDYEVA senior laboratory assistant (1962-1999)

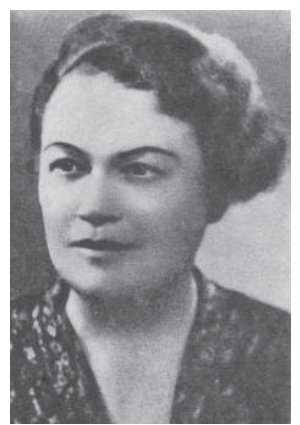

Bronisława KOKOSZYŃSKA (1939-1946)

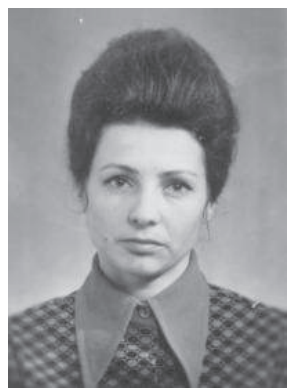

Ludmila KOSARCHYN (1980-1985)

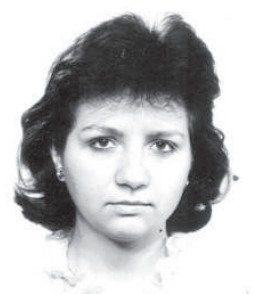

Oxana KIRCHANOVA leading custodian of funds (since 1986)

Fig. 1. Heads and support staff of the Geological/Paleontological Museum of Lviv University. 
The funds of the Paleontological Museum number more than 18 thousand exhibits from different parts of the world, the age range is from more than 600-540 Ma to modern representatives of fauna and flora.

Collections are exhibited in 6 halls (Departments of Systematic Paleontology, Historical Geology, Regional
Paleontology, Anthropogen Biota, Paleoecology, Monographic Department, and new expositions are being prepared) (Fig. 2-7). The total area is $300 \mathrm{~m}^{2}, 72$ windows and 16 stock cabinets are involved.

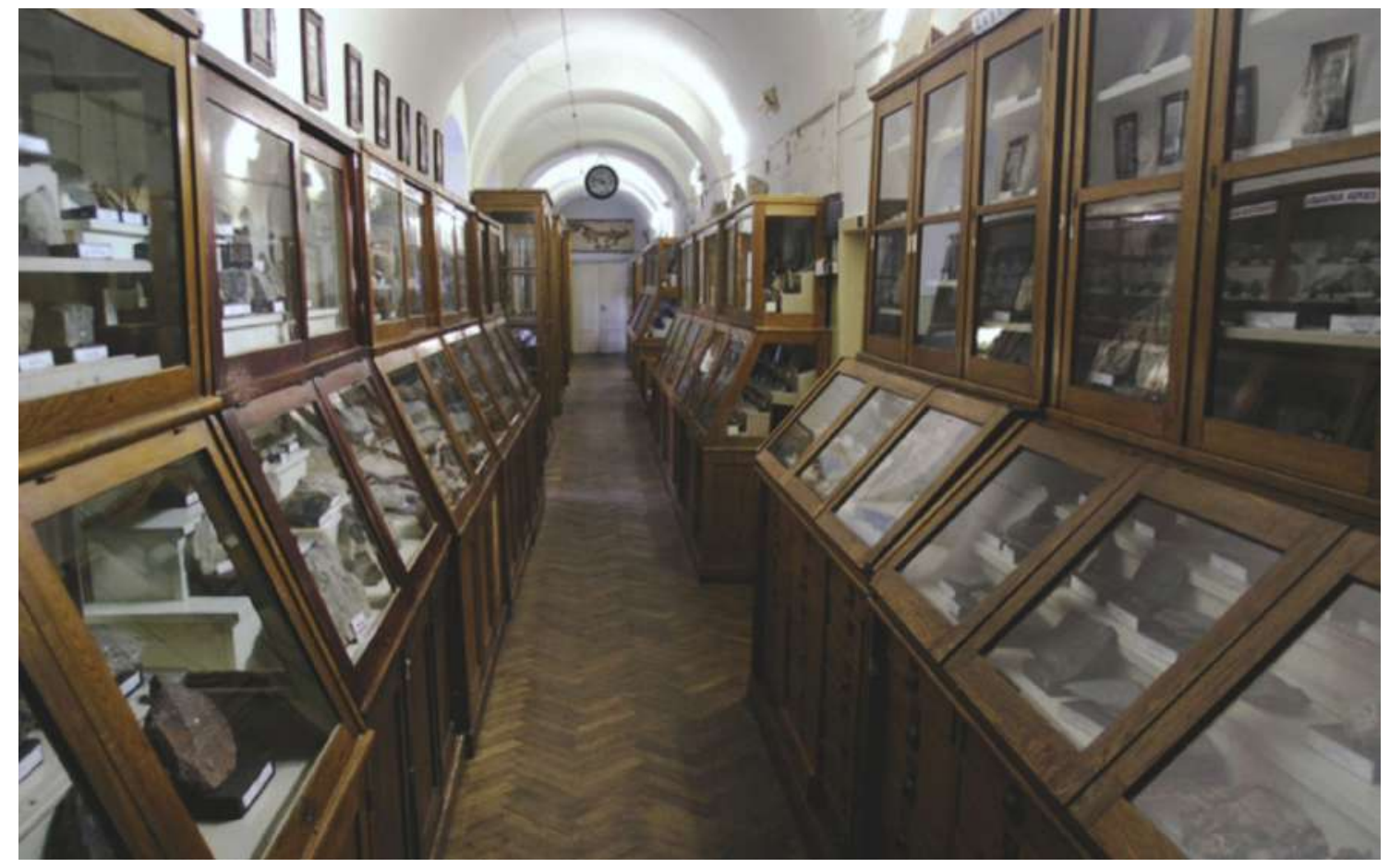

Fig. 2. Department of Systematic Paleontology. The exposition demonstrates the organization of life from the simplest (unicellular) forms to more complex (multicellular chord).

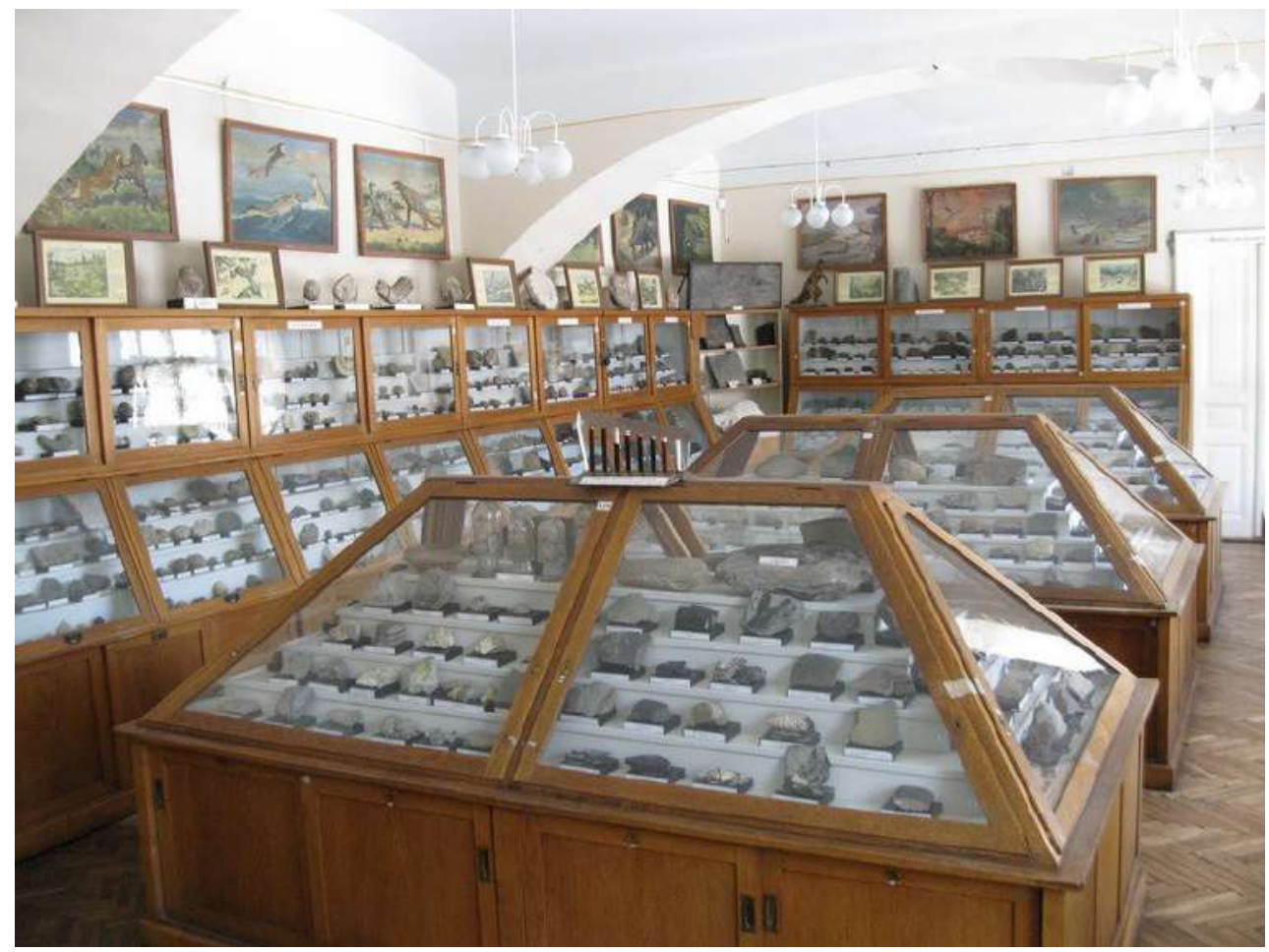

Fig. 3. Department of Historical Geology or Earth History. The exposition demonstrates the variety of forms and morphological features of the fossil of the corresponding geological era from Vendian (Ediacaran), Cambrian to Anthropogen. 


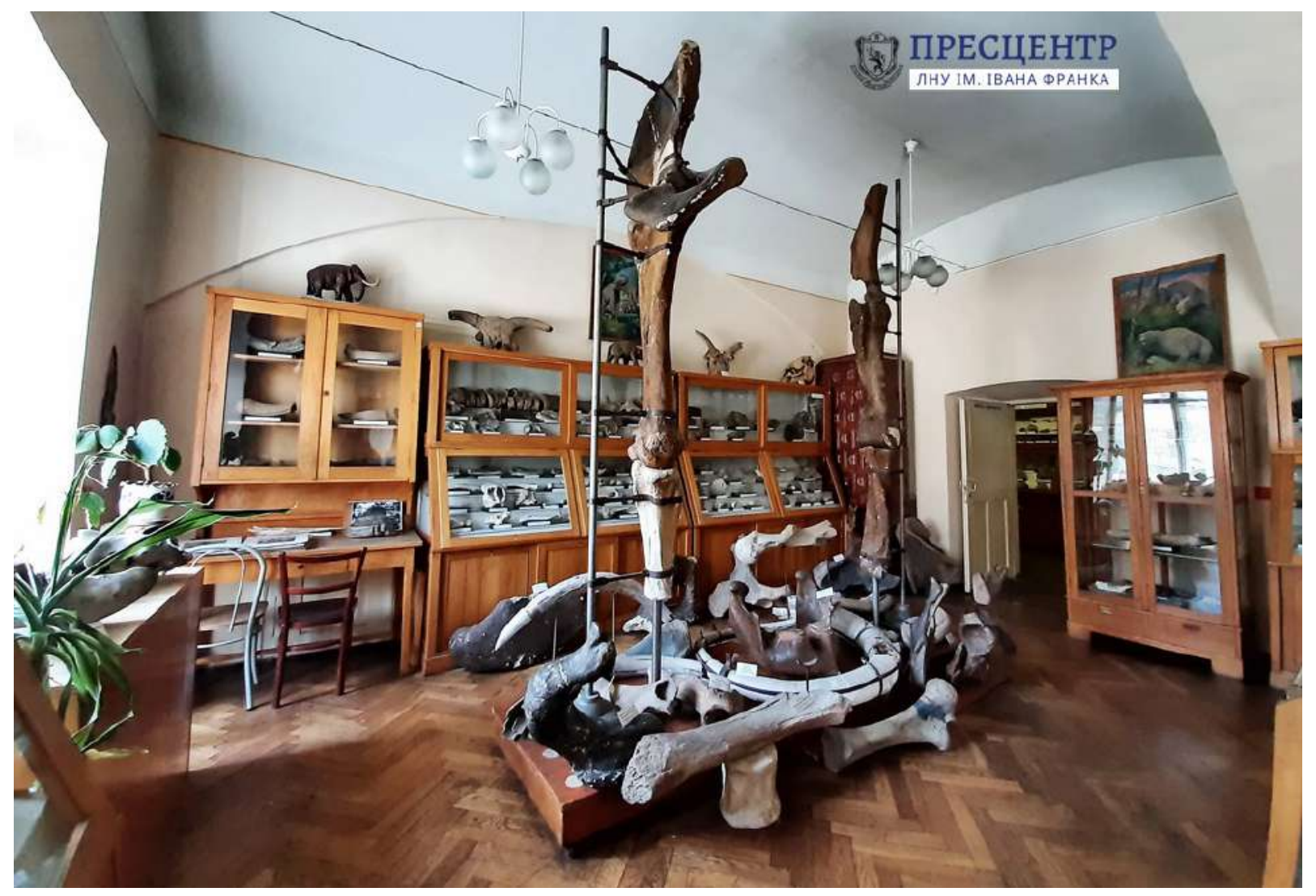

Fig. 4. Anthropogenic Biota Department. The exposition demonstrates the variety of forms and morphological features of representatives of the modern world.

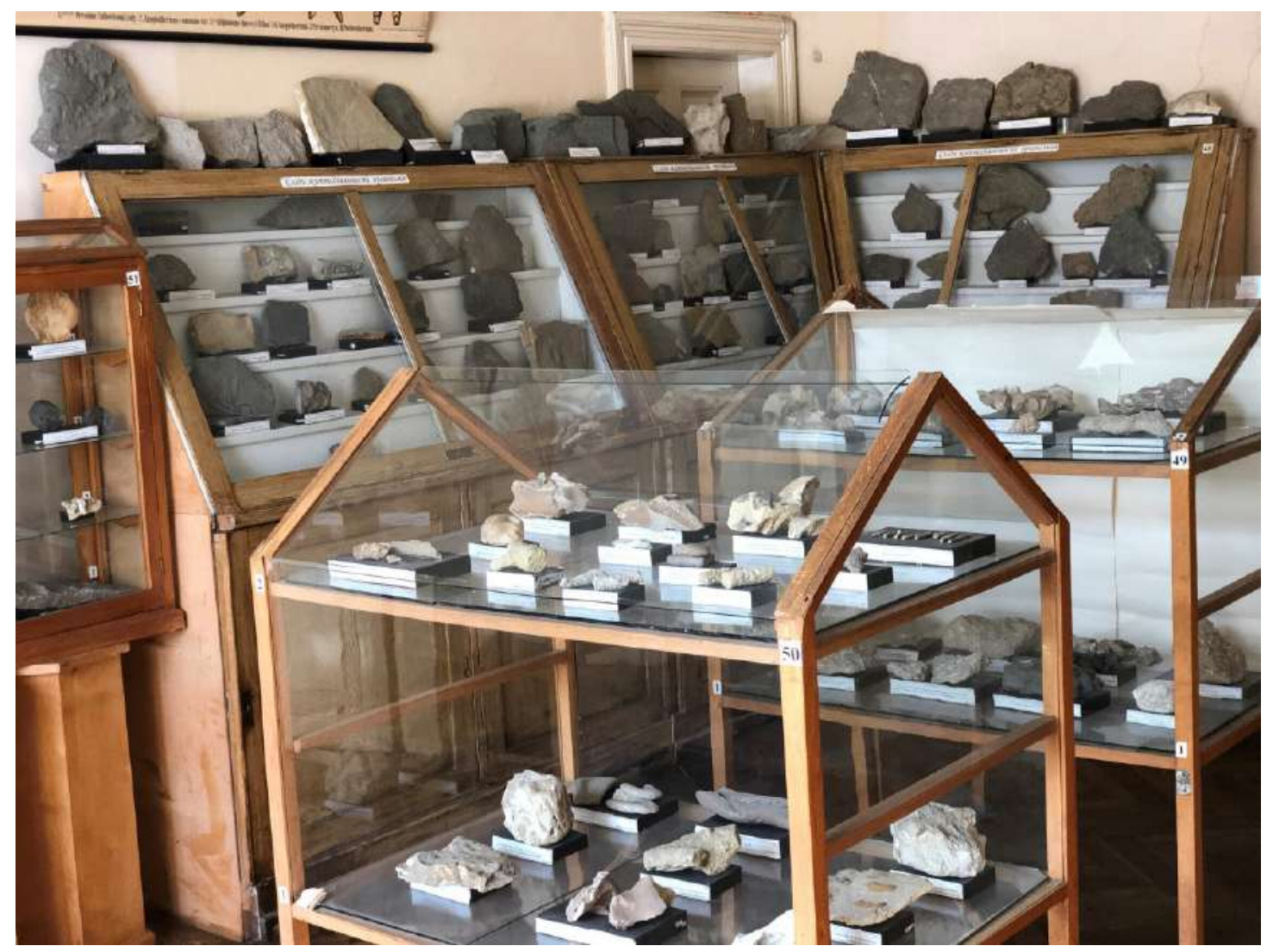

Fig. 5. Department of Paleoecology. The exposition demonstrates the variety of traces of vital activity (bioglyphs) and traces of the activity of physical factors of the environment (mechanoglyphs). 


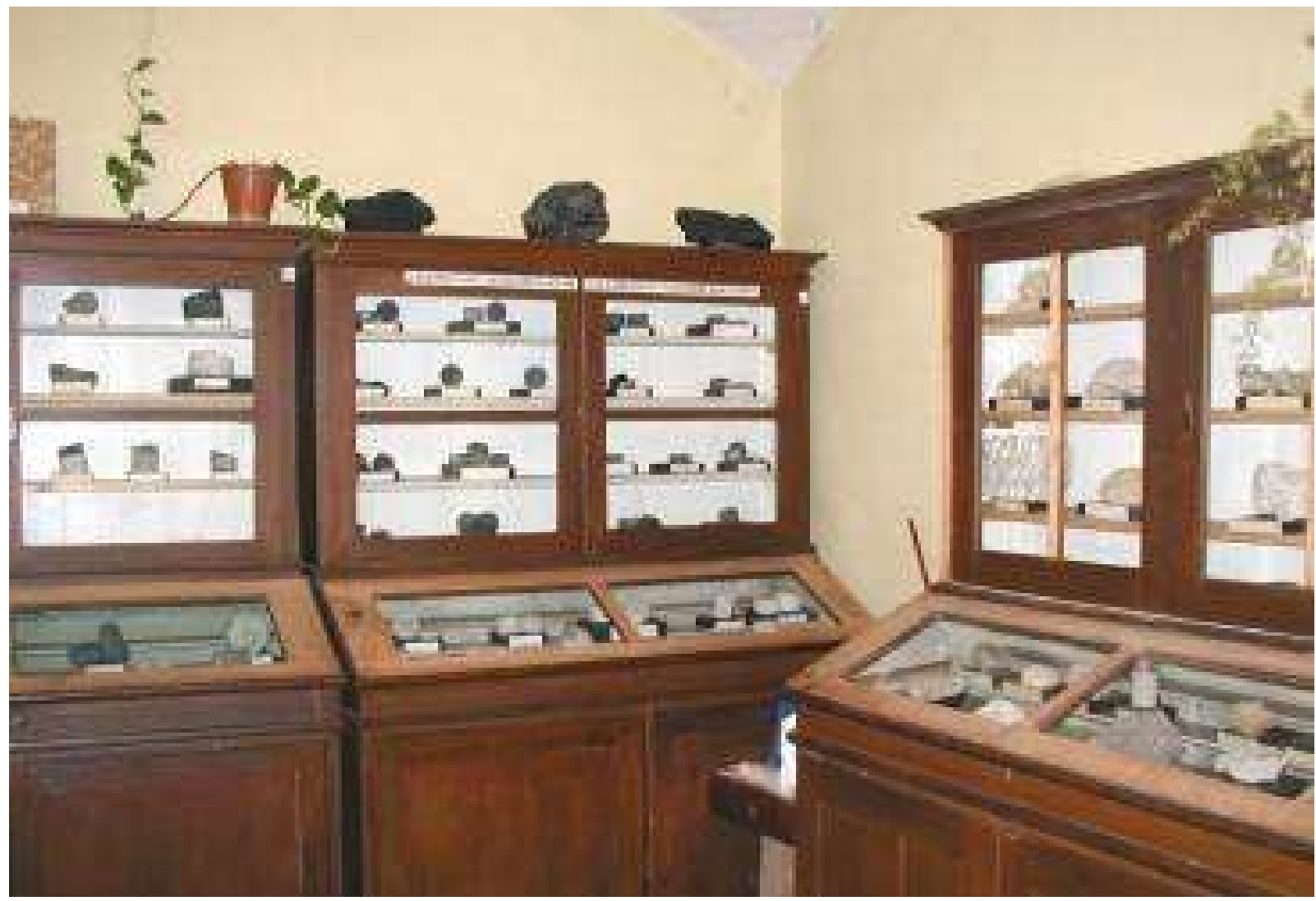

Fig. 6. Department of Regional Paleontology. The exposition demonstrates the fauna and flora complexes of the corresponding period of time of a single territory of Ukraine.

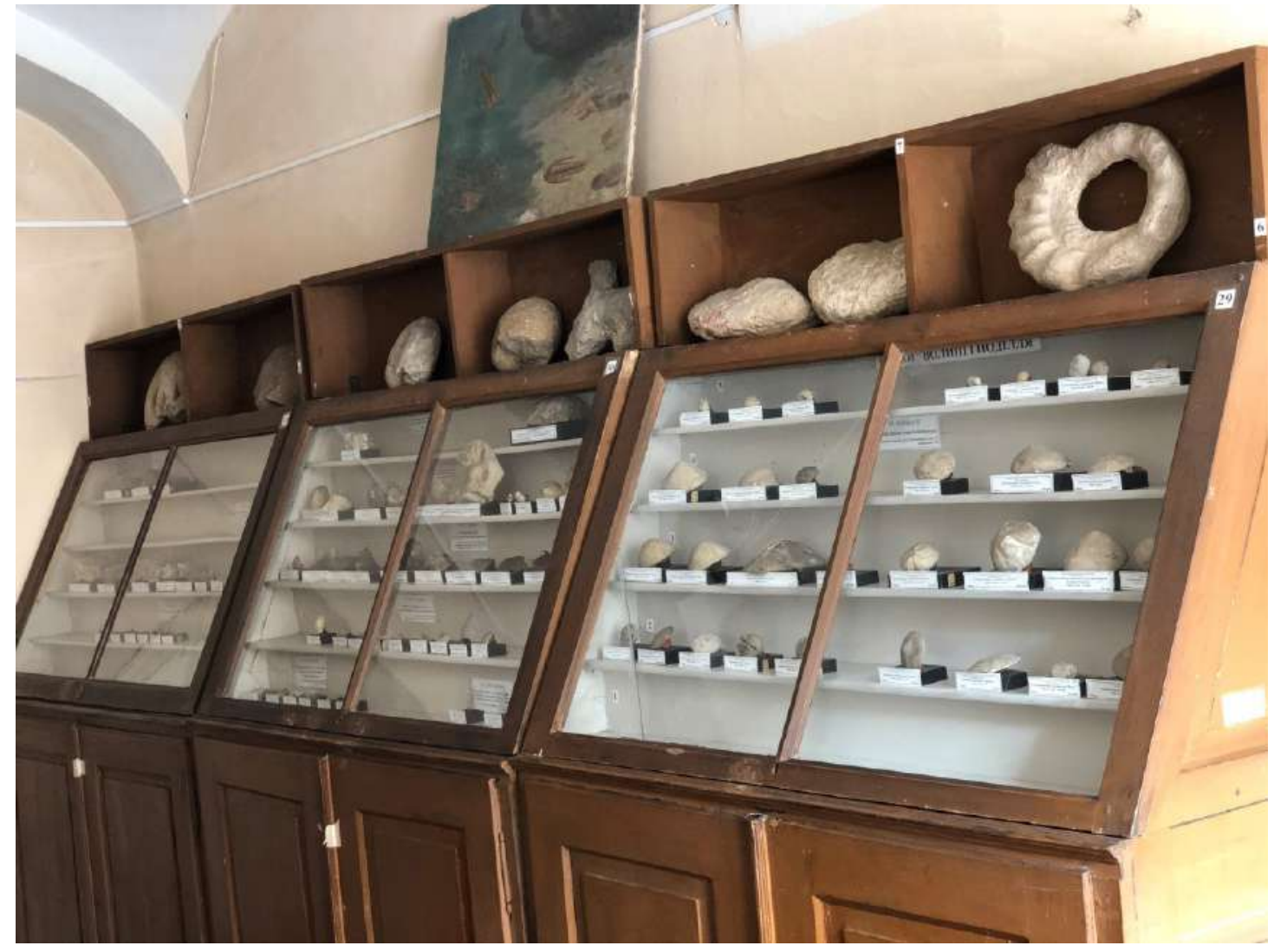

Fig. 7. Monographic department. The exposition shows collections gathered and studied in the process of research by geologists and paleontologists of different generations and periods. 
At the present stage, the Paleontological Museum with a long history, unique exhibits and their number, attractions constitutes a system of material culture, the key elements of which are cultural (historical, memorial) and Natural Heritage. In addition, the Paleontological Museum can be considered as a component of museum studies (or museology). This is an interdisciplinary science that studies the laws of the development and functioning of museums, or a science that forms at the intersection of social and humanitarian knowledge and studies the laws of the genesis and functioning of the museum, its interaction with cultural and natural heritage, as well as society. One of the priority areas of research of the Paleontological Museum as a scientific and educational-cultural institution is the generalization of accumulated empirical material, the systematization of conclusions, the formation of the ideology of the modern museum. As R. Man'kovska (Man'kovska, 2009) notes today, the approach to understanding the subject of the museum has changed. Previously, the museum's significance of the subject was predetermined by its rarity, aesthetic value, memoriality, informativity, and the museum became more important for the subject. Today, a significant part of museologists believes that the museum should not be based on objects that belong to it, but on ideas that he wants to convey to the visitor. Therefore, recently, museology has more and more decisively brought to the fore the issues of the museum's content as an educational institution, its prospects, the influence on society and on the formation of public consciousness.

Paleontological Museum of Lviv University as an object of historical, cultural and natural values.

Museum collections formed in the walls of universities in different countries of the world have often become and become the basis of great modern national museums, that is, they first arose in universities and thanks to universities.

\section{Samoylenko}

Cultural heritage. In this context, the Paleontological Museum reflects the aspect of the formation of natural sciences at Lviv University and in the West of Ukraine, the contribution of a single generation of geologists to the development of geological and paleontological sciences. Museum funds document the processes and phenomena that occurred in the natural environment at different periods of geological time and had an influence on living organisms. The use of a materialistic worldview and a systemic approach in the knowledge of the Universe and planet Earth as a component of macroand microspase contributed to the study of its structure, composition, processes and phenomena, and also influenced the formation of the main scientific concept of the Paleontological Museum, which consists in understanding and presenting:

1. Patterns of origin, organization, accumulation and localization of matter in space and time.

2. Patterns of emergence, development, functioning and interaction of modern and fossil ecosystems of various levels of organization and subordination.

3. Patterns of evolution of the biosphere and the biotic development on the Earth (in particular, morphology, lifestyle and environments of ancient organisms, their appearance and disappearance).

4. General patterns of the influence of environmental factors on living organisms, including humans.

Knowledge and understanding of these patterns, identification and assessment of threatening factors are the key to the conservation of natural resources and the health of the population with the prediction of their development and negative consequences.

Today, the collections of the Paleontological Museum can be classified by purpose into monographic, exposition, exhibition and educational ones; in importance - unique, rare and valuable.

Monographic paleontological collections (Fig. 7) are collections that have become the basis for paleontological studies of various scientific areas of natural disciplines (in particular, Earth Sciences) and are covered in publications (articles, review works, regional paleontological reports, monographs, atlases, directories, as well as manuscripts and reports) of scientists. Their uniqueness is determined by the presence of reference specimens of international importance - holotypes, lectotypes, neotypes, paratypes of fossil species, first discovered and described from the territory of Ukraine. The scientific and practical significance of monographic paleontological collections is the use of new paleontological collections in determining residues, substantiating the age of sediments, in further studying and comparing with them, and building models of sedimentary basins of different ranks.

Exposition and exhibition - collections that correspond to the thematic departments of the Paleontological Museum. For example, the department of systematic paleontology demonstrates the organization of life from the simplest (unicellular) forms to the more complex (multicellular chord) (Fig. 2). Department of Historical Geology - the exposition demonstrates the variety of forms and morphological features of the corresponding geological era from Vendian (Ediacaran), Cambrian to Anthropogen (Fig. 3). Department of Anthropogen Biota - the exposition demonstrates the variety of forms and morphological features of representatives of the modern world (Fig. 
4). Department of Paleoecology - the exposition shows a variety of traces of vital activity (bioglyphs) and traces of the activity of physical factors of the environment (mechanoglyphs) (Fig. 5). Department of Regional Paleontology - the exposition demonstrates the fauna and flora complexes of the corresponding period of time of a single territory of Ukraine (local level) (Fig. 6).

Educational collections - individual fossils or their associations, which are used for independent (creative) work by students. The study of fossils complexes is of fundamental and applied importance. The fundamental is the justification of the allocation of local and regional stratigraphic units of various ranks and subordination, the determination of biostratigraphic criteria when comparing with the units of the ICC and the construction of models of sedimentary basins. It is applied in search of mineral deposits. In this context, fossils and geological sections (stratotypes) are a reference material that serves as an object for comparison with other analogues of the regions of Ukraine and the world, and forms a scientific and theoretical base for stratons allocation by stratigraphic methods, accumulation and localization of industrial mineral deposits in the lithosphere. This aspect determines the value and uniqueness of collections of regional paleontology. Such sections with a complex of fossils remains should have natural conservation status directly in the natural environment, presentation, and preservation in the Paleontological Museum for study, comparison and refinement in future studies.

Educational collections are individual fossils or their associations, which are the objects of study in the process of independent (creative) work of students. The collections of fossil remains of the Paleontological Museum are used in the educational process by students of geological, biological, geographical faculties and the Natural College of Lviv University, pedagogical specialties of other educational institutions. The structure and subjects of the Paleontological Museum are consistent with the training programs of courses on the basis of paleontology, systematic paleontology, historical geology, evolution of the biosphere, interesting paleontology, stratigraphy, biostratigraphy, paleoecology, sedimentology, paleogeography, methods of paleontological research, geoecology. The museum funds are constantly used in the educational process and during scientific work at the Geology Faculty.

Historical and memorial heritage. Paleontological (geological) objects are actual material or objects of scientific research, studied with the subsequent publication of the results in the field of natural sciences (in particular Earth Sciences) rightly form a scientific, historical and memorial heritage. Museum funds (collections, research works, old printed books) and other objects of the Paleontological Museum form the cultural and national treasure. They reflect not only the foundations of the foundation of the «temple of muses» of geological sciences in Eastern Europe, but also, starting from the $19^{\text {th }}$ century, keep scientific research improvements (more than 250 scientific works) of more than one generation of world-class geologists (paleontologists) working at Lviv University for 200 years.

The publications can be classified according to the content as follows: 1) paleontological, devoted to the systematics and classification of fossil organisms, the description and illustration of new taxa (holotypes, neotypes, lectotypes, paratypes), the creation of atlases of taxa with their comparison with analogues of other regions; 2) stratigraphic, highlighting the problems of dismemberment and correlation of formations by fossils complexes, substantiation of rock age by comparison with ICC, determination of biostratigraphic value of fossil groups for the corresponding segment of geological time; 3 ) litho-facial, paleoecological and paleogeographic, the purpose of which is to clarify the habitat conditions of paleoorganisms, reproduce sedimentation and reconstruct the situation of continents and oceans; 4) climatic, dedicated to determining the distribution and position of climatic zones in space and time; 5) works of geological content clarifying the idea of structural-tectonic units of the territory of Ukraine and adjacent regions, an understanding of the processes and mechanisms of their formation; 6) works revealing the problems of nature conservation maintenance of the territory of Ukraine. These are, in particular, publications on geotouristic objects of natural origin (paleontological, stratigraphic) and historical and architectural monuments erected from natural decorative stones that form or can claim the status of a National or World Heritage. 7) Works of biographical content that illuminate the life and creative path of prominent figures, famous scientific researchers who have made a significant contribution to the development of the Earth Sciences; 8) popular science articles, the main purpose of which is the promotion of the university and museum.

At the present stage, the scientific and cultural refinement of the Paleontological Museum consists of more than 250 scientific (monographs, atlases, articles) (Vyalov, 1966; Goretsky, Venglinsky, 1979; Venglinsky, 1975; Leschukch, 1982; 1987; 1992; 1999; 2020; Sheremeta, 1969, etc.), educational and methodological (determinants, manuals), information and reference publications, guides, biographical messages. All this together reproduces the history of the formation and periods of development of natural sciences in the West of Ukraine, which should be preserved for the next generations, each time replenishing with new artifacts.

Nature-conservation heritage. In this context, the paleontological collections of Natural (Paleontological) 
museums as natural monuments have a significant advantage (Anfimova, 2011). The museum, on a limited area, presents such a variety of fossil remains «in space and time» that it is not possible to detect in a natural environment. This contributes to the involvement of museum collections in research, educational and cognitive processes and the popularization of the scientific direction of paleontology among various segments of the population. The nature-conservation significance of the paleontological collections of the Paleontological Museum of LNU is that they: 1) contain objects not only discovered on the territory of Ukraine, but also beyond its borders - significant geography of the remains distribution; 2) cover a significant age (stratigraphic) interval - from billions of years to modern representatives of fauna and flora; 3 ) found in various structural-tectonic elements of the sedimentary cover of Ukraine and the World (platform and complex areas); 4) retain representatives of the organic world of those territories that are impossible to access at the present stage as they are destroyed (natural or artificial) outcrops, reforming the coal industry and creating industrial parks based on them (The concept of reforming the coal industry..., 2020), features of the geological structure - «closeness» of the territory (deposits at significant depths and opened exclusively with the help of wells), limited access to the territories of the nature reserve fund, the location of sections from which fossils were selected, in the territories of other countries; 5) constitute the scientific-theoretical (fundamental) and applied base of geological sciences (Earth sciences).

The Paleontological Museum stores reference samples (holotypes) - first discovered and described from the territory of Ukraine, which are of the world importance. Among them there is the collection of traces of the life of O.S. Vyalov, the objects discovered and described come from the Miocene molasses of the Pre-Carpathian region (Vyalov, 1966, etc.). Today, only a few of such places are known - these are Hungary, Death Valley (USA), Kazakhstan). The remains of the mammoth (teeth, tusks, blades, ribs, feet, cervical vertebrae, parts of the spine, front and hind limbs), found in the vicinity of Lviv and in the quarry with Alekseevka, Mykolayiv region; the variety of fossils from Silurian of the Volyn-Podillya, the sections of which are considered the reference for the East European platform and the best in the world, and can claim world recognition; a collection of fossils from Jurassic lithographic shales, Zolengofen (Germany), an exhibit of one of which is stored in the Paleontological Museum of LNU; fossils from the global stratotype of Devonian deposits of the Czech Republic in the exposition of the Paleontological Museum of the LNU; collections of Mesozoic and Cenozoic invertebrates from the Paris basin, Western and Eastern Carpathians
(Leschukch, 1982; 1992), Mountain and Plain Crimea (Leschukch, 1987; 1992; 1999; 2020); a collection of flora samples from coal deposits in the Czech Republic, England, USA, Canada; a collection of fish from deposits from different countries of the World (remains of shellfish from the lower Devonian of Scotland, a cemetery of Devonian primitive fishes from Volyno-Podillya; a collection of fish remains from the menilite shales of the Carpathians a collection the tools of an ancient man (flint nuclei, pointed arrows, knives, scrapers, sickles, incisors, hammers). etc.) found in different places in Western Ukraine, etc.

\section{Conclusions}

In the modern sense, the Paleontological Museum is a structural unit of Ivan Franko National University of Lviv - a special socio-cultural multifunctional institution in the natural science field, which collects, explores, studies, exhibits and preserves natural monuments (paleontological exhibits)-collections of fossils (fossils of biogenic origin) (the vast majority) and other natural objects (geological and mineralogical), etc. for the purpose of implementation research, educational and informative, cultural and educational, popularization and propaganda (advertising) and environmental activities, as well as it can be considered as a center of innovative technologies.

Over the almost 200-year history of the existence of the Paleontological Museum of Lviv University, its museum funds and collections have been significantly replenished. Every year, the museum receives interesting, unique and rare exhibits that deserve the attention not only of scientists as the objects of research, but also of ordinary visitors as evidence of life. In recent years, Natural Museums (including Paleontological ones) have become relevant as various segments of the population familiarize themselves with the creations of Nature and evidence of life. In a limited area (several hundred square meters), an incredibly rich variety of fossils (naturals) are concentrated - natural objects of various degrees of the matter organization (life). Given this, museums can be considered as a separate category of natural monuments as a part of the Geological Heritage of Ukraine (Anfimova, 2011) or, even, the World Heritage.

According to all criteria - the long history of formation and development, the scientific and theoretical concept underlying the functioning of the museum, the uniqueness, rarity and value of museum collections and foundations, research potential, significance for society and science, the Paleontological Museum deserves an honorary place in the Historical, Cultural and Natural Heritage of Ukraine. The loss of such an object will have negative consequences for the development of science and society. 


\section{Referenses}

Anfimova, H. V., 2011. Paleontologichni kolekciyi yak geologichni pam'yatnyky (na prykladi Krymc'kogo region). [Paleontological collections as geological monuments (using the example of the Crimean region)]. Geologichni pam'yatky - yaskravi svidchennya evoluciyi Zemli: zb. mater. II Mizhnar. nauk.-prakt. konf. Kyiv: Logos. 14 (In Ukranian).

Bilonizhka, P., Matkovsky, O., Pavlun', M., Slyvko, E., 2010. Geologichny fakultet Lvivskoho natcional'noho universytetu imeni Ivana Franka (1945-2010). [Geological Faculty of Ivan Franko National University of Lviv (1945-2010)]. Dovidkovo-informaciyne vydannya. Lviv: Vydavnychy tcentr LNU im. I. Franka. 518 p. (In Ukranian).

Bilonizhka. P., Matkovsky, O., Pavlun', M., Slyvko, E., Ivanina, A., 2020. Geologichny fakultet Lvivskoho natcional'noho universytetu imeni Ivana Franka (1945-2020). [Geological Faculty of Ivan Franko National University of Lviv (1945-2020)]. Dovidkovoinformaciyne vydannya. Lviv: Vydavnychy tcentr LNU im. I. Franka. 208 p. (In Ukranian).

Venglinsky, I. V., 1975. Foraminifery I biostratigraphiya miocenovych otlozheniy Zakarpatskogo progiba. [Foraminifera and biostratigraphy of Miocene deposits of the Transcarpathian deflection.]. Kiev: Nauk. dumka, 1975. 263 p. (In Russian).

Voloshynovska, O., Hotsanyuk, H., Ivanina, A., Leschukh. R., Mar'yash, I., 2015. Paleontologichnomu muzeyu u Lvivskomu natcional'nomu universyteti imeni Ivana Franka - 110 rokiv. [Paleontological Museum at Ivan Franco National University of Lviv - 110 years]. Materialy XXXVI sesiyi Paleontologichnoho tovarystva NAN Ukrainy "Stratotypovi rozrizy phanerozoyskyh vidkladiv Ukrainy: suchasny stan paleontologichnoyi vyvcheyjsti ta perspektyvy podalshyh doslidzhen"" i "Paleontologichna osvita ta paleontologichni kolekciyi”, 24-26 veresnya 2015 r., Lviv. Kyiv, 10-11 (In Ukranian).

Voloshynovska, O., Hotsanyuk, H., Leschukh. R., Ivanina, A., 2004. Paleontologiya at Ivan Franco National University of Lviv ( 80 rokiv kafedri istorychnoyi geologiyi ta paleontologiyi). [Paleontology at the I. Franko National University of Lviv (80 years in the Department of Historical Geology and Paleontology)]. Problemy stratygrafiyi phanerozoyu Ukrainy. Kyiv, 268-271 (In Ukranian).

Vyalov, O.S., Venglinsky, I. V., Golev, B. T., Goretsky, V. A., Gorbach, L. P., Kudrin, L. N., 1956. Geologichesky muzey Lvovskogo gosudarstvennogo universiteta im. Iv. Franko. (Kratkiy putevoditel'). [Geological Museum of Iv. Franko State University of Lvov (Short Guide).]. (In Ukranian).

Vyalov, O. S., 1966. Sledy zhyznedeyatelnosti organizmov $\mathrm{i}$ ich paleontologicheskoe znachenie. [Traces of the life of organisms and their paleontological significance.]. Kiev: Nauk. dumka, 165 p. (In Russian).

Goretsky, V. A., Venglinsky, I. V., 1979. Stratotipy miocenovych otlozheniy Karpatskich progibov I VolynoPodolskoy plity. [Stratotypes of Miocene deposits of the
Carpathian foredeeps and the Volhyn-Podolian plate.]. Kiev: Nauk. dumka, 264 p. (In Russian).

Koncepciya reformuvannya vugilnoi galuzi ta ekonomichnoyi I ekologichnoi transformaciyi vugilnyh regioniv Ukrainy do 2027 r. Zasidannya Koordynaciynoho tcentru z pytan' transformaciyi vugilnyh regioniv Ukrainy, 08.10.2020. [The concept of reforming the coal industry and the economic and environmental transformation of coal regions of Ukraine until 2027 Meeting of the Coordination Center for the Transformation of Coal Regions of Ukraine, 08.10.2020.]. 23 p. (In Ukranian).

Leschukh, R., Ivanina, A., Hotsanyuk, H., Shainoha, I., Tuzyak, Ya., 2006. Kafedra istorychnoyi geologiyi ta paleontologiyi. [Department of Historical Geology and Paleontology]. Dovidkovo-informaciyne vydannya. Lviv: Vydavnychy tcentr LNU im. I. Franka. 68 p. (In Ukranian).

Leschukh, R., 1982. Nyzhnyokreydovi amonity Ukrayinskych Karpat. [Lower Cretaceous ammonites of the Ukrainian Carpathians.]. Kyiv: Nauk. Dumka. 164 p. (In Russian).

Leschukh, R., 1987. Rannyokreydova fauna Rivnynnogo Krymu I Pivnichnogo Prychornomor'ya. [Early Cretaceous fauna of the Plain Crimea and the Northern Black Sea region.]. Kyiv: Nauk. dumka. 220 p. (In Ukranian).

Leschukh, R., 1992. Nyzhnya kreyda Zachodu I Pivdnya Ukrayiny. [Lower Cretaceous of the West and South of Ukraine.]. Kyiv: Nauk. dumka, 208 p. (In Ukranian).

Leschukh, R., 1999. Yurski vidklady Pivdnya Ukrayiny. [Jurassic deposits of the South of Ukraine.]. Lviv: Yevrosvit. 335 p. (In Ukranian).

Leschukh, R., Starzhynsky O., 2020. Mezozoyski vidklady pivdenno-zachidnoyi Ukrayiny i pryleglogo shelfu. [Mesozoic deposits of south-western Ukraine and the adjacent shelf]. Lviv: LNU imeni Ivana Franka. 220 p. (In Ukranian).

Man'kovska, R, 2009. Muzeologiya yak naukova galuz': suchsny dyskurs ta problema teoretychnogo integruvannya. [Museology as a scientific branch: modern discourse and the problem of theoretical integration]. Krayeznavstvo: naukovy zhurnal. Ch. 3-4. Kyiv, 136-144. (In Ukranian).

Muravska, S. V., 2018. Muzeyni zaklady u systemi vyschoyi osvity Zachidnoi Ukrainy na tli svitovyh tendentciy. [Museum institutions in the system of higher education of Western Ukraine against the background of world trends]. Tcentr pam'yatkoznavsnva NAN Ukrainy i UTOPIK. Lviv. 244 p. (In Ukranian).

Tuzyak, Ya. Paleontologichny muzey Lviv Natcionalnoho Universytetu na mezhi tysyacholit': istoriya, etapy stanovlennya, suchasny stan. [Paleontological Museum of Lviv National University on the verge of millennia: history, stages of formation, modern state]. International scientific and practical conference "Challenges, threats and developments in biology, agriculture, ecology, geography, geology and chemistry": conference 
proceedings, July 2-3, 2021. Lublin,: “Baltija Publishing", 2021, 186-190 (In Poland).

Tuzyak, Ya. Conceptual and theoretical model of Natural Museums in the paradigm of modern education. The XXVI International Science Conference «Topical issues of practice and science», May 18-21, 2021, London, Great Britain. 2021, 150-153.

Tuzyak, Ya. Paleontological Museum of LNU: prerequisites for creation, formation stages, substantiation of the value of collections and expositions, its importance to society. The 2 nd International scientific and practical conference "Modern directions of scientific research development" (August 4-6, 2021) BoScience Publisher, Chicago, USA. 2021, 133-143.

Sheremeta, V. G., 1969. Ostrakody paleogena Ukrainy. [Ostracod of the Paleogene of Ukraine.]. Izd-vo Lvovskogo universiteta imeni Ivana Franko, Lvov. 261 p. (In Russian). 